\title{
Misplaced health expectations at the G8 summit
}

Previously published at www.cmaj.ca

$\mathrm{T}$ his weekend, Canada will host the G8 summit. With the primary focus on economic issues, a select few of the world's leaders will try to formulate a coherent consensus statement aimed at mobilizing resources to improve global maternal health. For a group that excludes developing countries - especially large emerging economies such as Brazil, China and India - to attempt meaningful policy initiatives toward global development is bewildering. Such a forum can only raise expectations that will not be met, yet again.

Having chosen to highlight a motherhood issue (literally), Prime Minister Stephen Harper sabotaged his own agenda by excluding funding for access to therapeutic abortion from any agreement, reportedly against the advice of Canadian civil servants. Experts and organizations such as the WHO agree that lack of access to safe therapeutic abortion accounts for $12 \%$ to as much as $30 \%$ of maternal deaths in various parts of the developing world. ${ }^{1}$

The public quickly recognized that one cannot develop a maternal health initiative without including abortion. Such a policy would be doomed to fail because it sentences one-third of women to death in some parts of the world. Yet the public outcry over an opportunity seemingly wasted is misplaced: it incorrectly assumes that the G8's consensus declarations on health are useful and effective means for change.

If history is any guide, G8 declarations on health will accomplish little. Mr. Harper is by no means the first G8 leader to tackle a global health problem. In fact, the G8 has made dozens of health promises, especially in the last decade. ${ }^{2}$ However, consensus statements have led to few new programs or only limited mobilization of resources aimed at improving health outcomes in developing countries.

Take AIDS. As far back as 1987, the G8 (then the G7) warned that "AIDS is one of the biggest health problems in the world" and called for "full political support and the necessary financial, personnel and administrative resources." ${ }^{\prime 3}$ But rhetoric did not translate into coordinated action. By the late 1990s, the rich countries of Western Europe, North America and Asia Pacific mustered barely US\$100 million of foreign aid annually for AIDS in Africa. ${ }^{4}$ That is only $\$ 5$ per HIV-infected person the price of a sandwich. Not until 2001 did the G8 create the Global Fund for AIDS, Tuberculosis and Malaria, which is still underfunded today. For those surprised that in the modern medical age AIDS could surpass the Black Death of seven centuries ago, this is how.

Hunger is no better. When the G7 summiteers met in Ottawa three decades ago, they affirmed "the importance of accelerated food production in the developing world and of greater world food security." ${ }_{5}$ However, there was no major push against chronic hunger; on the contrary, the share of foreign aid that rich countries give for agriculture is down about three-quarters. ${ }^{6}$ No wonder that the proportion - not just the number - of hungry people in developing countries is rising again.

The sensible conclusion to draw from these and other failures is that the G8 summit should focus solely on economic issues. It seems to be the wrong forum to seek real progress on global health issues.
The right forum must incorporate a group of national leaders, including the G8, and cannot be restricted to a few rich countries. It should include developing countries, notably at least a few from underdeveloped Africa. It should be accompanied by related meetings of health ministers, as often occurs with G8 finance ministers. It should aim to drive change in entire health systems rather than make isolated pronouncements on constantly shifting themes. Perhaps the G20 conference, being more inclusive, might better meet some of these criteria. Or maybe it's time for the world's most prominent health leaders to take the initiative and create a parallel meeting.

World leaders, particularly the economic powerhouses of the G8, might also begin addressing health and well-being as an economic issue. Doing so would entail investing in broad-based long-term health strategies rather than opting for new piecemeal programs only suited for press releases. Ensuring that any new health priority is supported and aligned through the Global Fund is another important role for the leaders of the G8.

Even modest investments in a developing country's health and social infrastructure could boost productivity and consumption - and, in turn, the ability of leading economies to prosper through trade. Economic development of this kind is the only truly long-term global stimulus package.

\section{Amir Attaran LLB DPhil}

Canada Research Chair in Law, Population Health and

Global Development Policy

University of Ottawa

Ottawa, Ont.

Paul C. Hébert MD MHSc

Editor-in-Chief, CMAJ

\section{Matthew Stanbrook MD PhD}

Deputy Editor, Scientific, $C M A J$

With the editorial advisory team: Ken Flegel MDCM MSc and Noni MacDonald MD MSc

Competing interests: See www.cmaj.ca/misc/edboard.shtml for editorial advisory team statements. None declared for Amir Attaran.

\section{CMAJ 2010. DOI:10.1503/cmaj.100770}

\section{REFERENCES}

1. Khan KS, Wojdyla D, Say L, et al. WHO analysis of causes of maternal death: a systematic review. Lancet 2006;367:1066-74.

2. Kirton J, Guebert J. Health accountability: the G8's compliance record from 1975 to 2009. Toronto (ON): University of Toronto; 2010. Available: www.g7 utoronto.ca/scholar/kirton-guebert-health-091228.pdf (accessed 2010 June 11)

3. Chairman's statement on AIDS. G7 Summit; 1987 June 8-10; Venice (Italy). Toronto (ON): University of Toronto; 1995. Available: www.g7.utoronto.ca/summit/1987venice/aids.html (accessed 2010 June 10)

4. Attaran A, Sachs J. Defining and refining international donor support for combating the AIDS pandemic. Lancet 2001;357:57-61.

5. Relations with developing countries. G7 Summit; 1981 July 20-21; Ottawa (ON). Toronto (ON): University of Toronto; 1995. Available: www.g7.utoronto.ca/summit/1981ottawa/communique/develope.html (accessed 2010 June 10).

6. Food insecurity in the world 2009: economic crises - impacts and lessons learned. Rome (Italy): Food and Agriculture Organization of the United Nations; 2009. Available: www.wfp.org/content/state-food-insecurity-world-2009. (accessed 2010 June 10). 